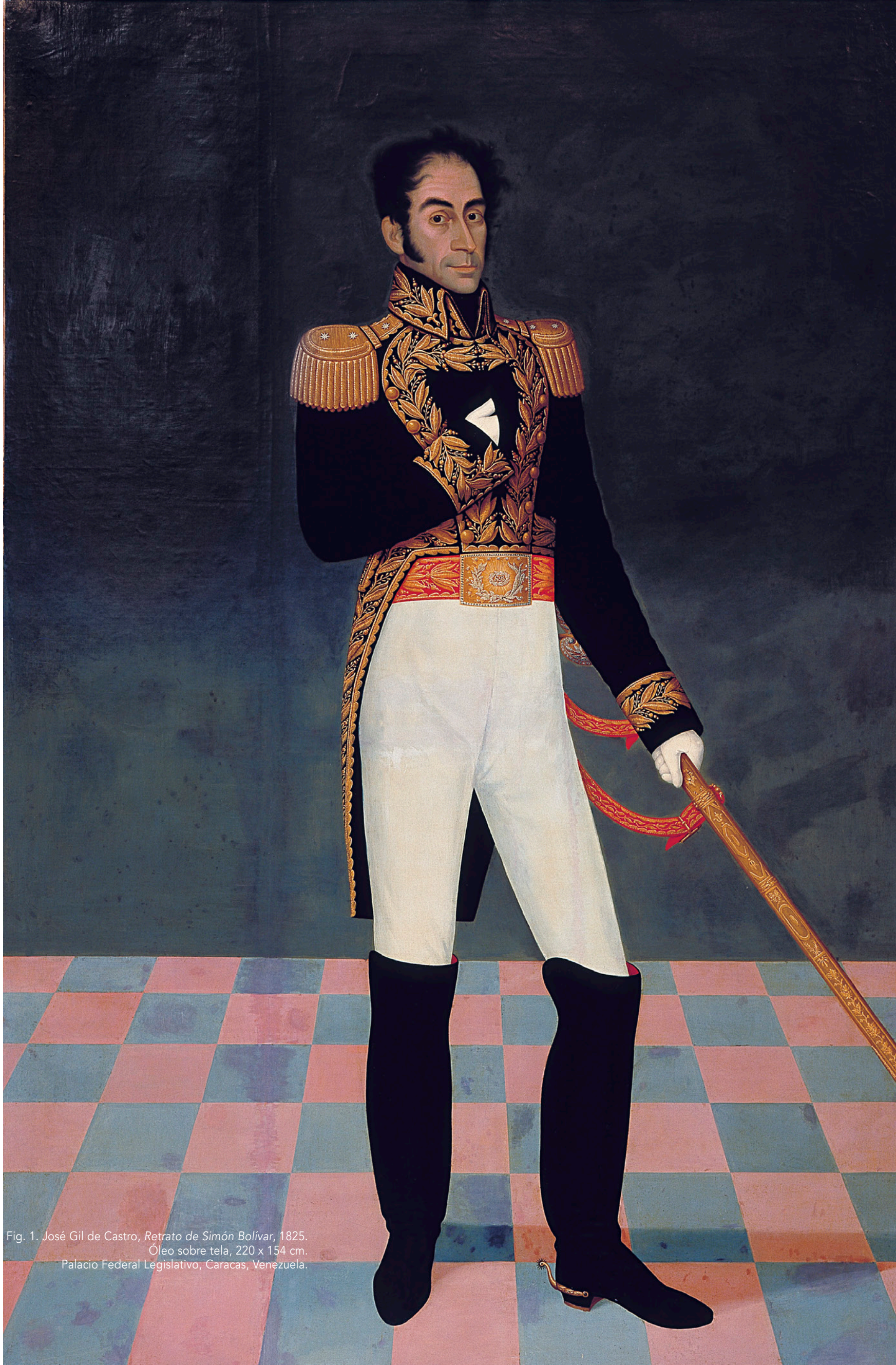




\section{La pintura venezolana de finales del siglo XVIII y principios del XIX. Lenguajes en tránsito}

Venezuelan Painting at the End of the XVIII Century and Early XIX Centuries: Languages in Transit

\section{Janeth Rodríguez Nóbrega}

Universidad Central de Venezuela, Caracas, Venezuela

janethrodriguezn@gmail.com https://orcid.org/0000-0003-0494-4925

\section{Resumen}

Este artículo presenta una revisión histórica de la pintura venezolana a finales del siglo XVIII y principios del XIX, con el propósito de mostrar los distintos lenguajes pictóricos que conviven de manera simultánea, en un período turbulento de la historia política y social del país. Pero también cuestionar algunos mitos historiográficos sobre los artistas venezolanos y su práctica artística durante estas décadas. Para ello nos enfocaremos en la vida y obra del pintor Juan Lovera (1776-1841), considerado por sus contemporáneos como el retratista más importante de Caracas. Su pintura fue una combinación de la práctica artística barroca y el nuevo lenguaje clásico, que cumplió con las necesidades representativas de la

\begin{abstract}
This article presents a historical review of Venezuelan painting in the late eighteenth and early nineteenth centuries, with the purpose of showing the different pictorial languages that coexisted simultaneously during a turbulent period of the country's political and social history. In addition, we question some historiographical myths regarding Venezuelan artists and their artistic practice during these decades. For this, we will focus on the life and work of the painter Juan Lovera (17761841), considered by his contemporaries as the most important portraitist in Caracas. His painting combined baroque artistic practice with new classical language, meeting the needs of Caracas society. This resulted in the misunderstanding of later academic criticism and
\end{abstract}

Cómo citar este trabajo / How to cite this paper:

Rodríguez Nóbrega, Janeth. "La pintura venezolana de finales del siglo XVIII y principios del XIX. Lenguajes en tránsito." Atrio. Revista de Historia del Arte, no. 25 (2019): 148-169.

(C) 2019 Janeth Rodríguez Nóbrega. Este es un artículo de acceso abierto distribuido bajo los términos de la licencia Creative Commons Attribution-NonCommercial-ShareAlike 4.0. International License (CC BY-NC-SA 4.0). 
sociedad caraqueña. Esto trajo como consecuencia la incomprensión de la crítica académica posterior y de la moderna historiografía del arte, que solo apreciaron su obra desde sus valores históricos.

Palabras clave: pintura venezolana; siglo XVIII; Juan Lovera; siglo XIX; historiografía del arte; Caracas. modern art historiography, which only appreciated his work based on its historical values.

Keywords: Venezuelan painting; 18th century; Juan Lovera; 19th century; art historiography; Caracas.

\section{Introducción}

Si hay una época que ha sido poco apreciada por la disciplina histórica venezolana, marcada por un nacionalismo a ultranza y un acérrimo antihispanismo, ha sido este momento de transición entre el antiguo régimen y la república. Durante años la mayoría de los historiadores concentraron sus esfuerzos en la descripción detallada de la gesta militar independentista, en la biografía de los héroes y en los proyectos políticos e ideológicos, descuidando otros aspectos de la vida cotidiana. Mientras en el campo de la historia del arte escasamente se ha avanzado más allá de la identificación y revalorización de algunos artistas. Poco sabemos sobre el comercio y la circulación de imágenes y artífices, así como sobre el uso de la emblemática revolucionaria, y el auge de la miniatura como género pictórico, por solo mencionar unos ejemplos de temas muy puntuales.

Es preciso reconocer entonces que si se desea revisar la práctica artística de este período solo se hallan grandes obstáculos: dificultad para acceder a las fuentes, desaparición de los acervos documentales, escasez editorial y hasta una producción artística dispersa y arruinada por el paso de los siglos, la cual en ocasiones ha sido apreciada como de escaso valor artístico.

En este sentido nuestro artículo ${ }^{1}$ intentará una aproximación a este momento, repleto de lenguajes en tránsito que nos muestra un panorama aún impreciso y heterogéneo. Para ello vamos a privilegiar un enfoque descriptivo de la escena artística caraqueña, pero también intentaremos una visión crítica al abordar algunos mitos historiográficos que se han forjado alrededor de ciertos artistas de este período, especialmente el pintor Juan Lovera.

\section{Los últimos ecos del barroco}

Hasta los ańos finales del siglo XVII las provincias de Tierra Firme que conformarían el futuro territorio de la actual Venezuela eran una parte de la periferia del imperio español: unas regiones pobres, parcialmente aisladas y marginales con respecto a los virreinatos. Las reformas borbónicas modificaron parte de esta situación a través de una integración territorial tardía que dio origen a la Capitanía General de Venezuela en 1777, de la cual sería la ciudad de Caracas la capital administrativa, política y militar.

Este interés de la Corona española evidencia el protagonismo que había alcanzado la provincia de Caracas sobre el resto de las regiones circunvecinas, gracias a un crecimiento económico sostenido en la

1. Este trabajo inédito es una revisión de la ponencia presentada en la V Cátedra Latinoamericana de Historia y Teoría del Arte Alberto Urdaneta. Artes, sociedad y cultura en la Colombia de Bolívar 1770-1830. Universidad Nacional de Colombia, Instituto de Investigaciones Estéticas, Bogotá, Popayán, Ríohacha, 2011. 
exportación de rubros como el cacao, añil y café hacia los puertos del Caribe y la Nueva España. ${ }^{2}$ Para explotar económicamente este territorio se creó la Real Compañía Guipuzcoana en 1728, que se mantuvo en funcionamiento hasta 1784, e intentó redirigir casi toda la exportación de los productos caraqueńos hacia el mercado español.

La población de la provincia de Caracas a finales del siglo XVIII se calculaba en medio millón de habitantes, que se concentraban en la región noroccidental; y la ciudad de Caracas, la más poblada, albergaba la única Universidad (desde 1717), la Intendencia de Real Hacienda (1776), la Real Audiencia (1786), el Real Consulado (1793) y el Arzobispado (1803). Efectivamente esta ciudad era el centro económico y político, pero este protagonismo no se correspondía con un gran desarrollo urbanístico y una alta densidad demográfica. Hacia 1810 la zona urbana de Caracas apenas tenía un radio de siete cuadras, partiendo desde la plaza mayor, y contaba con unas ciento veinte manzanas. ${ }^{3}$

Este escenario no era muy diferente en el resto del territorio de la Capitanía. Según Rogelio Altez “a pesar del crecimiento de la segunda mitad del siglo XVIII, muchas de las zonas no cercanas al desarrollo de las capitales y puertos de envergadura, continuaban siendo un montón de rancheríos poco poblados y empobrecidos, con graves problemas de comunicación, sin caminos consolidados, con escasas riquezas y severos problemas de salud.” 4 Tan solo las ciudades de Caracas, Mérida y Maracaibo concentraban buena parte del desarrollo económico de la Capitanía.

La sociedad caraqueña de finales del siglo XVIII se balanceaba entre dos corrientes antagónicas: el pensamiento tradicional escolástico y las nuevas ideas ilustradas que ingresaban al territorio a través del comercio, tanto el legal como el clandestino. Sin embargo, el historiador Elías Pino Iturrieta sostiene que "el impacto de las nuevas ideas fue recibido de manera muy disímil, con diferentes grados en su aceptación y asimilación"5 en distintas áreas del saber, por lo que podríamos afirmar que esta modernidad impactó más en el pensamiento político e ideológico que en la práctica pictórica.

Así encontramos la tímida presencia de algunas formas neoclásicas, pero circunscritas al ámbito del repertorio de las artes decorativas, compitiendo con las formas rococó; y empleamos precisamente el término formas, porque en ambos casos no pasa de ser una moda ornamental en la cual se combinan motivos de variado origen, pero sin asumir los componentes ideológicos y estéticos. Mientras que la pintura se mantenía apegada a los valores del barroco, no tanto en sus aspectos estilísticos, sino en sus funciones persuasivas. Además de evidenciar una amalgama de lenguajes diversos: desde los grabados europeos que se siguen empleando como modelos; la pintura novohispana, especialmente las obras de Miguel Cabrera (1695-1768) y José de Páez (1720-1790), que se conocían gracias al comercio con los puertos novohispanos; y los cuadros del puertorriqueño José Campeche (1751-1809) que llegaban a Caracas hacia finales del siglo XVIII. Toda esta rica variedad estilística e iconográfica coexistió en el amplio abanico del gusto y la sensibilidad barroca que, a diferencia del clasicismo, no era excluyente, por lo cual acumulaba y superponía tradiciones diversas.

2. Peter Michael McKinley, Caracas antes de la independencia (Caracas: Monte Ávila Editores Latinoamericana, 1993$), 14$.

3. Rogelio Altez, El desastre de 1812 en Venezuela: sismos, vulnerabilidades y una patria no tan boba (Caracas: Universidad Católica Andrés Bello, Fundación Empresas Polar, 2006), 319.

4. Altez, 100.

5. Elías Pino Iturrieta, La mentalidad venezolana de la emancipación (1810-1812) (Caracas: Eldorado Ediciones, 1991$), 205$. 
Algunos autores sostienen que para mediados del siglo XVIII la pintura local había alcanzado tal madurez que podríamos hablar de la existencia de una escuela caraqueña liderada por el maestro pintor, escultor y dorador criollo Juan Pedro López (n. 1727-1787), uno de los pocos creadores locales que había alcanzado a configurar un lenguaje artístico propio (Fig. 2). Su producción logró cotas de calidad y reconocimiento local, al punto que tuvo numerosos seguidores que copiaron con mayor o menor fortuna sus fórmulas estilísticas. Por ello el inventario actual de sus obras es extenso; con diversidad de calidades formales y técnicas, que aún requiere de nuevos estudios. Al respecto no se ha indagado sobre los discípulos y ayudantes en el taller de López, al contrario, se ha querido promover la idea romántica de que López no tuvo colaboradores, cuando en realidad su taller fue uno de los más productivos ocupado en tareas diversas, por lo que le habría sido imposible trabajar en solitario.

Tras la desaparición física de López en 1787 quedaron otros artistas produciendo en la capital. En el taller de la

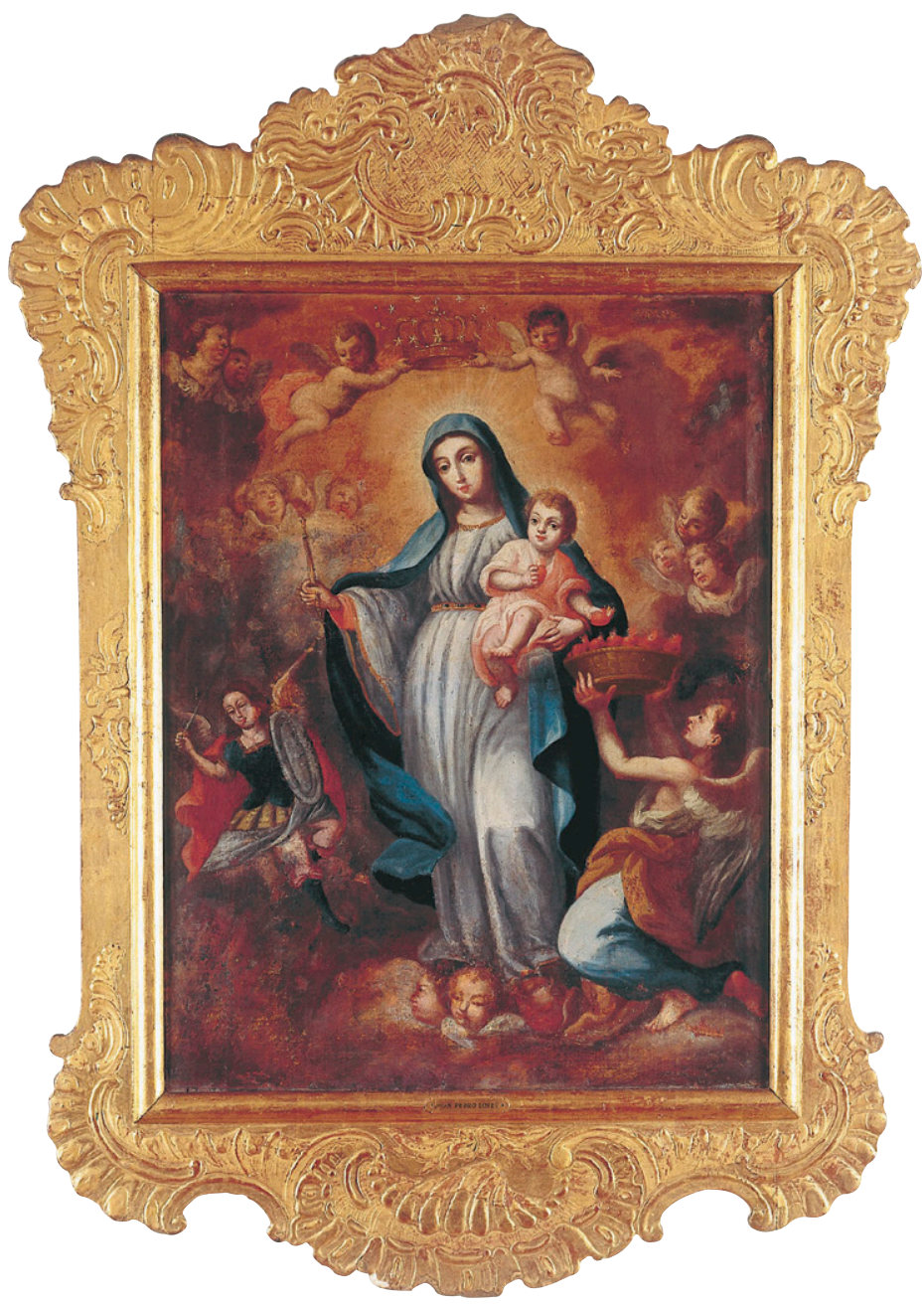

Fig. 2. Juan Pedro López, Nuestra Señora de la Luz, 1760. Óleo sobre tela, 65.4 x $50.2 \mathrm{~cm}$. Colección privada, Caracas, Venezuela. familia Landaeta varios de sus miembros alcanzaron cotas de calidad estética, como el maestro Antonio José Landaeta fallecido en 1799. Pero aún no se ha catalogado la producción de este taller (Fig. 3), lo que nos permitiría visualizar su desarrollo y su impronta local, así como tampoco se ha cuestionado las innumerables atribuciones, muchas de ellas obtenidas por presiones del mercado. Para complicar más el asunto hacia finales del siglo XVIII se hallan en Caracas cerca de veinticuatro familias que llevan el apellido Landaeta, pertenecientes a la clase de los pardos libres, ${ }^{6}$ y ocupadas en oficios artesanales, haciendo casi imposible la labor de identificación documental. Y si esto no bastara, Carlos Duarte advierte que "muchos de los varones de estas distintas familias fueron bautizados con nombres propios muy comunes, como el de Juan José, y se ha encontrado que entre 1770 y 1810 existieron unos once individuos que lo llevaron." Entre estos, un Juan Landaeta que para 1811 se hallaba en Londres como aprendiz de pintor, bajo la protección de don Luis López Méndez, uno de los comisionados de la Jun-

6. El término pardo diluía las distinciones entre mulatos, zambos y gentes de color de sangre mezclada con ascendencia africana.

7. Carlos Duarte, Diccionario biográfico documental. Pintores, escultores y doradores en Venezuela. Período hispánico y comienzos del período republicano (Caracas: Fundación Galería de Arte Nacional, Fundación Polar, 2000), 124. 


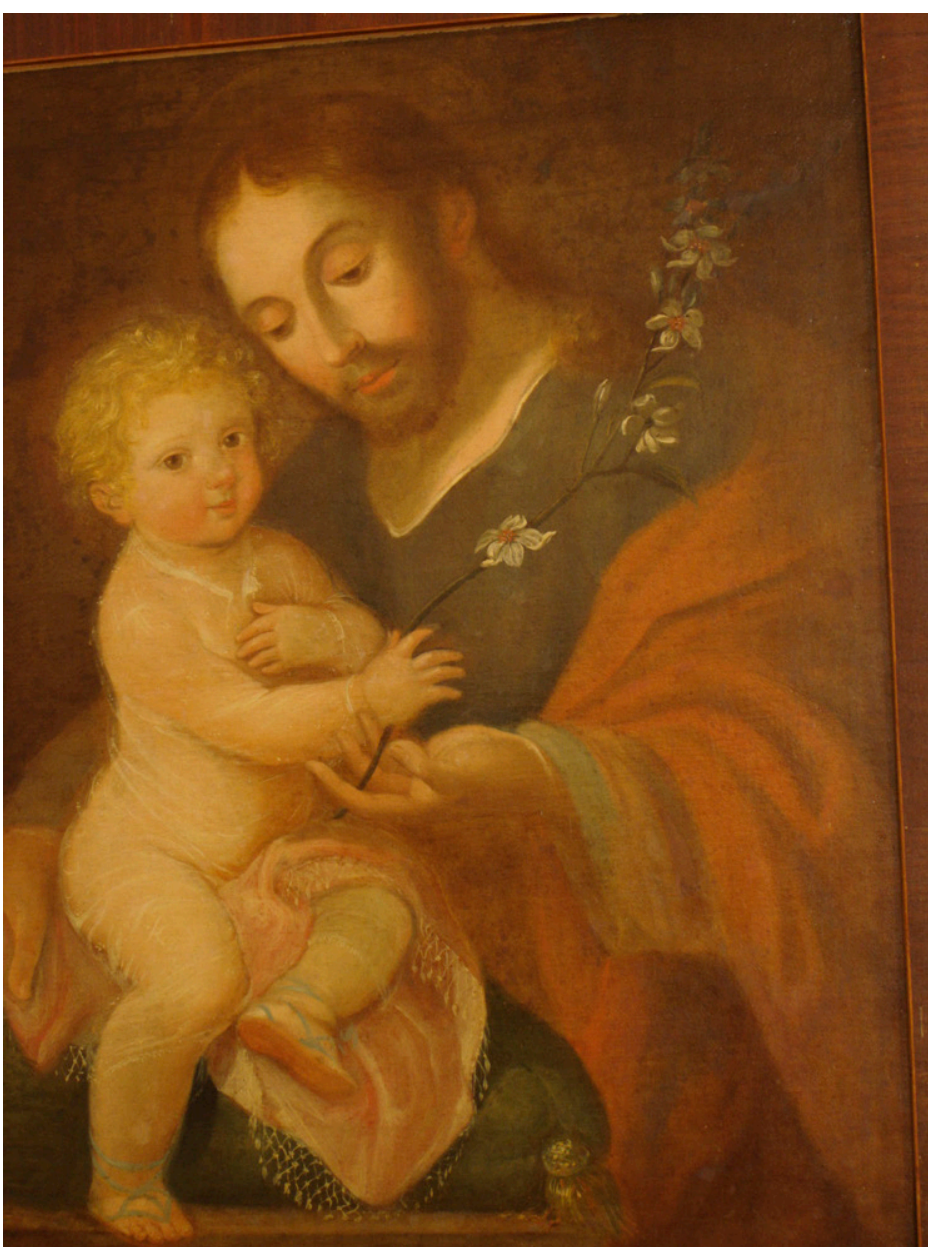

Fig. 3. Atribuido al taller de los Landaeta, San José con el Niño, c. 1790. Óleo sobre lienzo, $57 \times 44 \mathrm{~cm}$. Museo Diocesano de Coro Lucas Guillermo Castillo, Coro, Venezuela.

ta de Caracas ante el gobierno británico. ${ }^{8}$ Este Landaeta habría regresado al país en 1827, pero se desconoce cuál habría sido su destino.

La producción de López y del taller de los Landaeta, así como de sus seguidores, se caracteriza por una pintura atada al discurso religioso, con una iconografía convencional y repetitiva, que empleaba grabados de distinta procedencia como modelos. También hallamos la práctica del retrato civil, exclusiva de las elites, tanto peninsulares como criollas. Estos retratos de aparato se distinguieron por un estilo hierático, colmado de detalles, y con escenografías estudiadas. Además se aprecian calidades distintas entre las obras de tema religioso y los retratos efectuados por un mismo artista, lo que demuestra el apego al uso de estampas, mientras que apenas se conocía la práctica de la copia del natural. Por su parte, otros géneros como la naturaleza muerta y el paisaje son prácticamente inexistentes en los inventarios actuales, aunque sabemos por documentos que abundaban cuadros con estos temas, de manufactura europea, en las viviendas caraqueñas. En líneas generales, en este fin de siglo son pocos los artistas que muestran calidad de ejecución, la mayoría se encauza a repetir ciertas fórmulas estandarizadas. De todo ello nos atrevemos a afirmar que después de la desaparición física de Juan Pedro López y de Antonio José Landaeta, hay un fuerte declive en la calidad de la producción pictórica caraqueña.

Algunos artistas han sido vinculados con el taller de los Landaeta en calidad de discípulos, aunque creemos que se trató de oficiales que colaboraban ocasionalmente en algunos encargos, ya que ninguno de estos evidencia haber asimilado el lenguaje pictórico que caracteriza a los Landaeta. Entre estos artistas se puede mencionar a José Hilarión Ibarra (act. 1798-1854), autor de varios lienzos firmados, entre ellos un retrato del arzobispo Ramón Ignacio Méndez; un retrato ecuestre del Libertador que obsequió al mismo durante su visita a Caracas en 1827; y además se le ha atribuido la pintura mural de la Quinta Anauco en Caracas (actual Museo de Arte Colonial), encargada en 1828 por el Marqués del Toro, Francisco Rodríguez. Otro de los discípulos del taller de los Landaeta fue el pintor Juan Lovera, sobre quien profundizaremos más

8. Duarte, 119. 
adelante, por ser el ejemplo más representativo de esos lenguajes en tránsito.

Más allá del taller de los Landaeta en actividad hasta finales del siglo XVIII se ha registrado la firma de algunos artistas tras el dorso de ciertas obras. En este punto, conviene acotar que nuestros pintores rara vez firmaban su producción. Entre estas pocas piezas firmadas se encuentran los nombres de: Francisco Lovera (1795) a quien se atribuye la hechura de un San José con el Niño; un pintor de apellido López, del cual solo se conoce un retrato doble que representa a don Esteban Ponte y Blanco y a su esposa dońa María del Carmen Peláez, pintado en marzo de 1800; José Antonio Peñaloza (act. 1776-1803), autor de un par de retratos del obispo Mariano Martí en 1780 y de algunas imágenes religiosas; Francisco Contreras (1762-1819), autor de una Santísima Trinidad fechada en 1819 y de varias imágenes de santos; Manuel Zenón Romero (act. 1816-1840), artista dedicado a las labores de mantenimiento de la catedral; el presbítero criollo José María Xédler (act. 1798-1835), quien acostumbraba retocar algunos cuadros de su iglesia en el pueblo de Petare; Emeterio

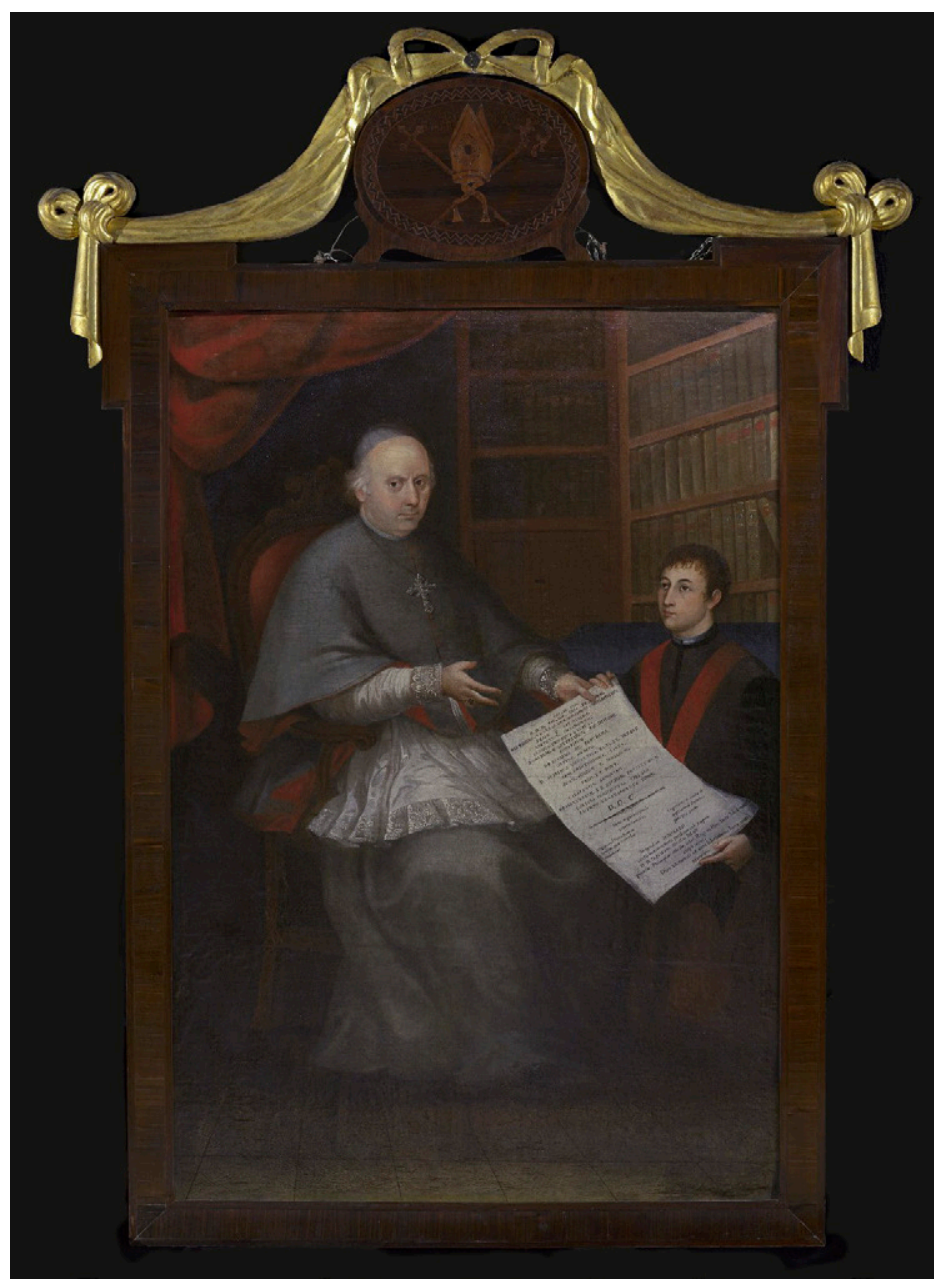

Fig. 4. Emeterio Emazábel, Arzobispo Narciso Coll y Prat y José Vicente Eulogio Ramón Ignacio de Jesús Rada y Verois, c. 1811. Óleo sobre tela, 194 x 139.7 cm. Brooklyn Museum, Nueva York, US. Disponible en: http://brooklynmuseum.org/opencollection/objects/210290 Emázabel (act. 1815-1830) quien pinta unos retratos del segundo arzobispo del país, Narciso Coll y Prat (Fig. 4); y Joaquín de Sosa (act. 1806-1840), de quien se conoce una Divina Pastora, fechada en 1822, en la Colección Patricia Phelps de Cisneros.

Otros nombres figuran en los documentos de empadronamiento y en los inventarios de testamentarias. Constantemente se mencionan pintores, en su mayoría pardos, de los cuales aún no se han podido identificar sus obras, por lo que estamos tentados a creer que se trataba de oficiales que trabajaban ocasionalmente en los grandes talleres, o de simples artesanos que se empleaban en labores diversas, pero que no dudaban en ofrecerse como "maestros de pintor" a más de un cliente desprevenido. Tal práctica era frecuente en Caracas ante la ausencia de un gremio que supervisara los talleres y controlara la formación de los artistas.

En la primera década del siglo XIX vamos a encontrar la llegada de algunos artistas extranjeros, como el dibujante, periodista y político italiano Francisco Isnardi (n. Turín, 1750), quien estuvo en Caracas entre 


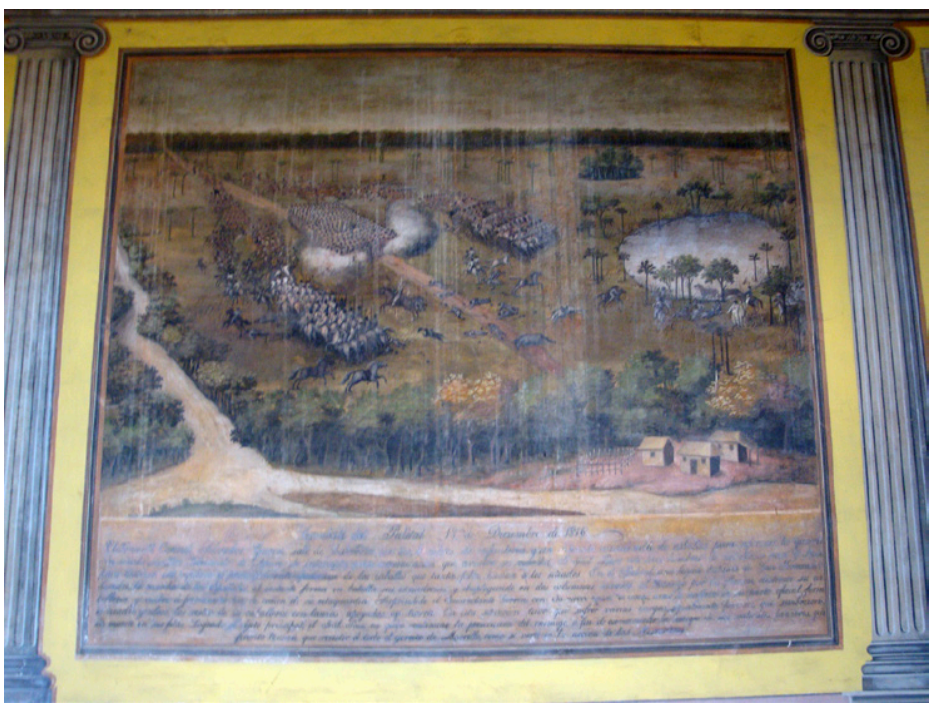

Fig. 5. Pedro Castillo, Combate del Palital 18 de diciembre de 1816, h. 1829. Pintura al temple sobre muro, 221 × $261 \mathrm{~cm}$. Casa Páez, Valencia, Venezuela.
1809 y 1812 , fecha en la cual es detenido por las tropas realistas y enviado a Cádiz. ${ }^{?}$ Durante su estadía diseñó el Monumento fúnebre en memoria de las víctimas de Quito, erigido por suscripción popular en la iglesia de Nuestra Señora de Altagracia. También colaboró con la prensa local, escribiendo algunos artículos en el Mercurio Venezolano e incluso fue el secretario del primer Congreso de Venezuela. Pero se desconoce su producción artística.

Otro artista extranjero fue el italiano Onofre Padroni (n. Roma, 1772), quien trabajó en Caracas desde 1801 a 1804, y del que tampoco han quedado vestigios de su obra. Durante su estancia tuvo varios aprendices como el futuro mé-

dico José de la Cruz Limardo (1787-1851), quien cuenta en sus Memorias escritas en 1843, haber asistido al taller de Padroni durante seis meses, maestro al que describió como un "romano de mucha moral y de suma destreza y gusto en la pintura." ${ }^{10}$ Padroni le insistió en continuar con sus estudios sin exigirle pago, por lo cual le ayudaba en otras tareas como decorar zócalos en las viviendas caraqueñas. ${ }^{11} \mathrm{Al}$ tiempo que practicaba el retrato en miniatura y copiaba las ilustraciones insertas en las traducciones de las obras de Virgilio y Horacio. Sin embargo, con la invasión de Domingo Monteverde (1773-1832) y el terremoto de 1812, Limardo interrumpió sus estudios y partió hacia las islas del Caribe. Regresó en 1822 y se estableció en El Tocuyo, donde optó por dedicarse a la medicina. La obra pictórica de Limardo aún no ha sido identificada.

Otro alumno de Padroni, fue el pintor Pedro Castillo (ca. 1788-1858) nacido en Villa de Cura y formado en Caracas, aunque se desconoce en cuál taller. Según los testimonios de su futuro yerno, Juan Antonio Michelena, Castillo a los dieciséis años "ya era pintor al óleo y había adquirido conocimientos en el ramo de pintura de ornamentación al fresco, paisajes, etc. y ejecutaba retratos con un parecido admirable, pues era muy buen fisonomista y le gustaba copiar del natural." ${ }^{12}$ Durante algunos meses tomó clases con Padroni, luego de lo cual se dedicó a la pintura mural con zócalos de estilo ilusionista que mostraban medallones con bustos de filósofos griegos, emperadores y matronas romanas. Entre 1824 y 1826 Castillo decoró el salón de sesiones del ayuntamiento valenciano con escenas de la guerra de independencia, y hacia 1829 emprendió tareas semejantes en la casa del general José Antonio Páez (1790-1873). Tales escenas bélicas ponen énfasis en las estrategias militares de los ejércitos y en la topografía del paisaje (Fig. 5), pero no fueron del consumo

\footnotetext{
9. Es poco lo que se conoce sobre la vida de Isnardi. Vivió una temporada en Ámsterdam, luego en la isla de Trinidad desde donde pasó a Guiria, luego a Margarita y en 1810 se encuentra en Caracas. Aquí fue redactor del Mercurio Venezolano y de El Publicista. Muere en Ceuta. Véase el estudio: Pino Iturrieta, La mentalidad venezolana de la emancipación, 77-78.

10. José de la Cruz Limardo, "1841, Memorias," en Fuentes documentales y críticas de las artes plásticas venezolanas: siglos XIX y XX, comp. Roldán Esteva-Grillet (Caracas: Universidad Central de Venezuela, Consejo de Desarrollo Científico y Humanístico, 2001), 1:138.

11. Duarte, Diccionario biográfico documental, 135.

12. Juan Antonio Michelena, "1859, Apuntes biográficos de Pedro Castillo, pintor y escultor en Valencia," en Esteva-Grillet, Fuentes documentales y críticas, 1:220.
} 
público, por lo no contribuyeron a la creación de la iconografía histórica de finales del siglo XIX. Castillo también retrató al general Páez y a toda su familia, aunque por motivos políticos estos retratos no se conservaron. Al tiempo que continuó pintando escenas religiosas y miniaturas, igualmente practicó la escultura y el dorado de objetos diversos.

Precisamente los testimonios de estos artistas nos revelan que desde las décadas finales del siglo XVIII estaba de moda la decoración ilusionista, con balaustradas, medallones con bustos de filósofos y escenas mitológicas, lo que perdurará durante buena parte del siglo XIX. Esta iconografía grecolatina lentamente se va introduciendo gracias al libre comercio y la presencia de artistas extranjeros, pero con muy poco impacto en la pintura de caballete.

Regresando a la estancia de Onofre Padroni en Caracas, llama la atención el interés de los jóvenes artistas por obtener una formación en dibujo; lo que llevó a Padroni a solicitar en 1804 el permiso para abrir una academia bajo el patrocinio del Real Consulado. En su solicitud alegaba: "Una falta de maestro y que es prueba nada equivoca en que en el corto tiempo que se han aprovechado de su enseñanza, ha dado luz a obras de mucho mérito (...) proporcionada por veinte alumnos [y que era] copioso el número de los que aspiran a instruirse." ${ }^{13}$ Pero no se conoce la identidad, ni las obras, de estos estudiantes.

Pese a que el Real Consulado vio con buenos ojos la propuesta, considerando como "fundamento de lo útil y beneficioso que será a estas Provincias," ${ }^{14}$ el capitán general Manuel de Guevara y Vasconcelos rechazó la solicitud el 11 de enero de 1805, alegando entre otras razones la presencia temporal de Padroni en Caracas, y una solicitud previa para fundar una academia de matemáticas y física que se había elevado ante el rey. Además, señaló que "el señor Capitán no le considera con los conocimientos y teoría que exige la enseñanza de ambas artes o con toda solidez." ${ }^{15}$ Ante esta negativa, Padroni decidió abandonar Caracas, y marchó a Bogotá, Lima y México, a donde finalmente arribó en 1806.

Otra iniciativa semejante fue tomada por el pintor cumanés Juan José Franco (n. 1779-act. 1814), quien se había formado en la Real Academia de Bellas Artes de San Fernando en 1798. En 1809 se instaló en Caracas y solicitó permiso al ayuntamiento para abrir una escuela de dibujo. Finalmente, no se autorizó el establecimiento porque la regencia de las escuelas debía estar "en manos de personas blancas". Pero le permitieron dar clases privadas "a aquellos que así lo deseen." ${ }^{16}$ Caracas tendrá que esperar hasta 1834 cuando el pintor Joaquín de Sosa le proponga a la Sociedad Económica de Amigos del País fundar una escuela de dibujo, que finalmente se instala al año siguiente. ${ }^{17}$

Sobre Juan José Franco se publicará un pequeño artículo en el Mercurio Venezolano, en febrero de 1811, en el cual se relata que fue el autor del primer grabado realizado en Caracas, que representa el Monumento fúnebre consagrado a las víctimas de Quito, que había sido dibujado por Isnardi. ${ }^{18}$ Hay que recordar

13. Roldán Esteva-Grillet, Vida y obra de Pedro Castillo (1790-1858) (Caracas: Biblioteca de la Academia Nacional de la Historia, 2004$), 27$.

14. José María Salvador González, "La enseñanza del arte en Venezuela durante la primera mitad del siglo XIX," Escritos en Arte, Estética y Cultura, no. 17-18 (2003): 176.

15. Salvador González, 177.

16. José Juan Franco, "1809, Solicitud de permiso para abrir una escuela de dibujo," en Esteva-Grillet, Fuentes documentales y críticas, 60.

17. Duarte, Diccionario biográfico documental, 265

18. Francisco Isnardi, "1811, José Juan Franco y el grabado," en Esteva-Grillet, Fuentes documentales y críticas, 1:64. 
que la imprenta no se estableció en Caracas, sino hasta 1808, pese a que el Real Consulado había solicitado permiso para su instalación en 1780, lo que fue negado por la Corona. Esto limitó la producción artística y literaria en el territorio venezolano durante el antiguo régimen.

Juan José Franco continuó su labor como grabador en el taller de imprenta del francés Juan Baillío, en donde se elaboró el primer papel moneda en noviembre de 1811, emitido por la primera república. Pero no se conocen otros testimonios documentales o materiales sobre su producción artística.

Por otra parte, sabemos que desde 1785 algunos artistas caraqueños se encontraban pensionados en Madrid, estudiando en la Academia de Bellas Artes de San Fernando. Tal es el caso de Antonio Benítez de Lugo y Veroiz (n. 1769), Antonio Matías Basterra (n. 1786), Rafael Cordoba y Berde, los hermanos José y Juan de la Cruz Cortines, Carlos Miyares, etc. Pero se desconoce el paradero de estos a partir de los sucesos políticos y militares que sacudieron la península ibérica desde 1808 .

En esos primeros años del siglo XIX localizamos la presencia de diversos miniaturistas, como el señor M.H. Garnezey, dibujante y pintor francés que ofrecía sus servicios como retratista en miniaturas y maestro particular de dibujo en la Gazeta de Caracas $^{19}$ de febrero de 1812; el español José Gabriel de Aramburu y Lizarralde (act. 1777-1818), quien ejercía además el cargo de escribano y notario de Caracas; ${ }^{20}$ José Peregrino Malcampo y López (n. 1808-1870), oficial del ejército, quien en 1827 hizo un retrato del Libertador el cual fue llevado a Inglaterra y del que se perdió el rastro; y el caraqueño Juan Bautista Ugalde (n. 1808-1860) cuya vida disipada lo llevó a dedicarse al arte de la miniatura en Madrid, en donde falleció en 1860. Valga acotar que el género de la miniatura comienza a despuntar en Caracas como una especie de tarjeta de presentación o de despedida entre amigos y familiares. Pero es un género que aún espera ser estudiado.

Los años cruciales 1808-1821

El 15 de julio de 1808 se conocieron en Caracas las noticias sobre la invasión francesa y las abdicaciones en Bayona. La reacción popular fue de lealtad absoluta a Fernando VII (1784-1833) y de violenta repulsa al ejército invasor. Ese mismo día se procedió a efectuar la ceremonia de jura colocando un retrato del rey Borbón en el dosel de la sala capitular, con la presencia de los miembros del cabildo civil y las autoridades provinciales; pero sin las pompas acostumbradas en estos eventos. Desde entonces se multiplicaron en Caracas las expresiones de lealtad hacia el monarca: se celebraron misas en su honor, se realizaron obras de teatro, procesiones y banquetes, se recogieron donativos para financiar la guerra en la península; y por supuesto, en todas estas actividades las imágenes del rey fueron las protagonistas.

Es de creer entonces que en este ambiente de lealtad exaltada se habrían encargado numerosos retratos de Fernando VII para engalanar todas las oficinas públicas, además de las salas de algunas viviendas. Como fue el caso del retrato que se le encargó al pintor Marcos Martínez en 1809 para entronizarlo bajo un dosel en la Universidad de Caracas. ${ }^{21}$ Sin embargo, esta producción retratística no sobrevivió a los aconteci-

19. Gazeta de Caracas, "1812, M.H. Garnezey, dibujante y pintor francés, se ofrece para hacer retratos en miniatura y dar clases de pintura," Esteva-Grillet, 1:73. 20. Duarte, Diccionario biográfico documental, 48.

21. Duarte, 198 
mientos posteriores al 5 de julio de 1811, cuando el Congreso repudió la monarquía y asumió la república como forma de Estado y de gobierno. En consecuencia, son escasos los retratos de la monarquía espańola conservados en Venezuela. ${ }^{22} \mathrm{Y}$ creemos que más de un retrato del algún criollo, confundido en pose y vestimenta con la nobleza europea, sufrió también los rigores iconoclastas de este momento histórico; lo que explicaría la discrepancia entre el número de retratos que se mencionan en los documentos y los conservados.

No vamos a detenernos en narrar los acontecimientos que marcaron la fundación de la primera república y su posterior disolución. Tampoco profundizaremos en las vicisitudes de la guerra de independencia. Pero si es importante recordar que:

El proceso que tuvo lugar durante este breve pero complejísimo período modificó la vida de todos los venezolanos. Los habitantes de Venezuela dejaron de ser súbitos de la corona y se convirtieron en ciudadanos, vieron abolir los fueros y privilegios y sancionar constitucionalmente la igualdad de todos (...) desaparecieron los cargos hereditarios y venales y se dio inicio al ejercicio del voto y a las prácticas republicanas. También hubo un dramático descalabro económico, pérdidas materiales de proporciones considerables, muchas de las viejas fortunas coloniales quedaron sensiblemente disminuidas, los sectores desposeídos no vieron mejorar sus condiciones de vida, la población disminuyó en proporciones inimaginables, calamidades y carencias de diferente tipo fueron parte de la vida cotidiana de los venezolanos durante esos años de violencia y guerra. ${ }^{23}$

A esta situación hay que agregar los devastadores terremotos del 26 de marzo de 1812 y sus numerosas réplicas, que produjeron al menos dos mil víctimas en Caracas. ${ }^{24} \mathrm{La}$ ciudad "perdió las dos terceras partes de sus edificios, casi todas las iglesias parroquiales y las catedrales quedaron agrietadas y cuarteadas." ${ }^{25} \mathrm{La}$ destrucción casi total que provocaron los sismos dejó un territorio sin infraestructura de producción, caótico y desmotivado, que tardó décadas en reponerse; al punto que las ruinas formaron parte del paisaje cotidiano caraqueño hasta los últimos años del siglo XIX.

A su vez el inicio de la guerra de independencia, que duró casi una década, "profundizó y amplificó aquella destrucción, impidiendo y retardando la recuperación económica." ${ }^{26}$ En este punto conviene recordar, que pese al discurso grandilocuente de la historia: "La correspondencia y testimonios de la época reflejan muy claramente que el enfrentamiento se redujo a una guerra de exterminio, donde la muerte y la venganza condujeron a la destrucción total y con ella apareció la extorsión, la inclemencia, el saqueo, el furor, el hambre, la enfermedad, el dolor, el horror." 27

Solo la ciudad de Caracas perdió la mitad de la población durante la década bélica; muchos alistados en los ejércitos en pugna y otros huyendo en estampida ante la cercanía de las tropas, bien fueran realistas o patriotas. Situación que se repitió en diversas ocasiones, siendo la más famosa, la migración de 1814, cuando bajo las órdenes de Bolívar se desocupó Caracas, antes de la llegada de las tropas de José Tomás Boves (17821814). En esta huida hacia el oriente fallecieron cientos de caraqueños en los caminos. Así la ciudad quedó

\footnotetext{
22. Janeth Rodríguez Nóbrega, "El rey en la hoguera: la destrucción de los retratos de la monarquía en Venezuela," en VI Encuentro Internacional sobre Barroco. Imagen del poder, coord. Norma Campos (La Paz: Editorial Visión Cultural, 2012), 89-95.

23. Inés Quintero, coord., Más allá de la guerra. Venezuela en tiempos de la independencia (Caracas: Fundación Bigott, 2008$), 5$.

24. Rogelio Altez sostiene que se trató de dos epicentros simultáneos: uno cercano a Caracas y el Litoral central, y otro en la serranía de Aroa. Altez, El desastre de 1812 en Venezuela, 316.

25. Quintero, Más allá de la guerra, 213

26. Altez, El desastre de 1812 en Venezuela, 466.

27. Quintero, Más allá de la guerra, 215.
} 
desierta, lista para el saqueo de almacenes, bodegas, casas, etc., porque las órdenes de ambos ejércitos era no dejar piedra sobre piedra: quemar, destruir y acabar con cualquier propiedad que pudiera servir al enemigo. Si al cataclismo sísmico se le suma entonces la devastación producida por la guerra, podemos comprender que este período de transición se convirtió en una zona traumática en la memoria de los venezolanos.

La práctica pictórica durante la década bélica se redujo tan sensiblemente que apenas quedan vestigios documentales, y solo puede citarse la participación de algunos artistas en la decoración de los aparatos efímeros que se emplearon para recibir a las tropas victoriosas. Así se dieron casos de artistas que pintaron para ambos bandos, como Joaquín de Sosa, quien en 1819 pintó los retratos de Fernando VII y María Isabel de Braganza, para un catafalco en la catedral de Caracas; y en 1821 participó en la fabricación de un tablado para festejar el triunfo de los patriotas en la batalla de Carabobo. ${ }^{28}$ Otros artistas optaron por emigrar a las islas del Caribe, como fue el caso de Juan Lovera y José de la Cruz Limardo, escapando de los horrores de la guerra.

Lo cierto es que el impacto de las bajas demográficas no fue superado prontamente, como lo evidencia un informe que presentó la Sociedad Económica de Amigos del País, en el cual se señala que en toda la provincia de Caracas solo existían nueve pintores en actividad para $1833,{ }^{29}$ panorama muy distinto al de finales del siglo XVIII cuando proliferaban los artistas.

El fin de la guerra no produjo un florecimiento inmediato de la actividad pictórica, en un país sin estabilidad económica y política. El reinicio fue lento, asociado a la retratística de los héroes de la guerra, y a la fabricación política de imágenes que se expresaba en desfiles, homenajes y entradas triunfales que acompańaron el paso de los ejércitos; aunque sobre esto queden pocos testimonios.

Pese a la popularidad que comienza a adquirir la imagen de Bolívar, no se ha podido comprobar que algún artista venezolano haya tenido la oportunidad de representar al Libertador copiando su efigie directamente del natural. ${ }^{30} \mathrm{Y}$ tampoco hay constancia que los artistas caraqueños se hayan dedicado a representar la efigie del Libertador con fines comerciales, como acontece en otras ciudades americanas. Esta carencia de retratos de Bolívar fue resuelta en Caracas gracias a los enviados desde diversos puntos del continente, como las obras del quiteño Antonio Salas (Quito, ca. 1780-ca. 1860) o el famoso retrato efectuado por el peruano José Gil de Castro (Lima, 1783-1841) en 1825 y enviado por Simón Bolívar a su hermana María Antonia al año siguiente (Fig. 1).

Sobre el arribo de esta obra de Gil de Castro a Caracas no se ha estudiado su impacto en la producción local más allá de la creación de la iconografía bolivariana, y contrario a lo que pudiera creerse no se trató de una obra para el consumo privado, ya que se exhibió públicamente en julio de 1828, cuando se efectuaron festejos en honor al Libertador. En esa oportunidad, el retrato se llevó en procesión "acompañado de tropa, muchos oficiales con hachas encendidas (...) fue recibido con salva de artillería y colocado en un templete destinado al efecto" ${ }^{31}$ en la plaza mayor. Evento que recuerda las juras al monarca durante el antiguo régimen.

\footnotetext{
28. Duarte, Diccionario biográfico documental, 264-65.

29. Sociedad Económica Amigos del País, "1833, Cuadro general de artesanos según sus clases en la provincia de Caracas," en Esteva-Grillet, Fuentes documentales y críticas, 1:100

30. Roldán Esteva-Grillet, "Iconografía europeo-americana de Bolívar," en Studi Latinoamericani/ Estudios Latinoamericanos, No. 2: Nazioni e Identitá Plurime, coord. Mario Sartor (Udine: Universitá degli Studi di Udine, 2006), 161-88.

31. Esteban Palacios y Blanco, "1828, Carta a Simón Bolívar," en Esteva-Grillet, Fuentes documentales y críticas, 1:95.
} 


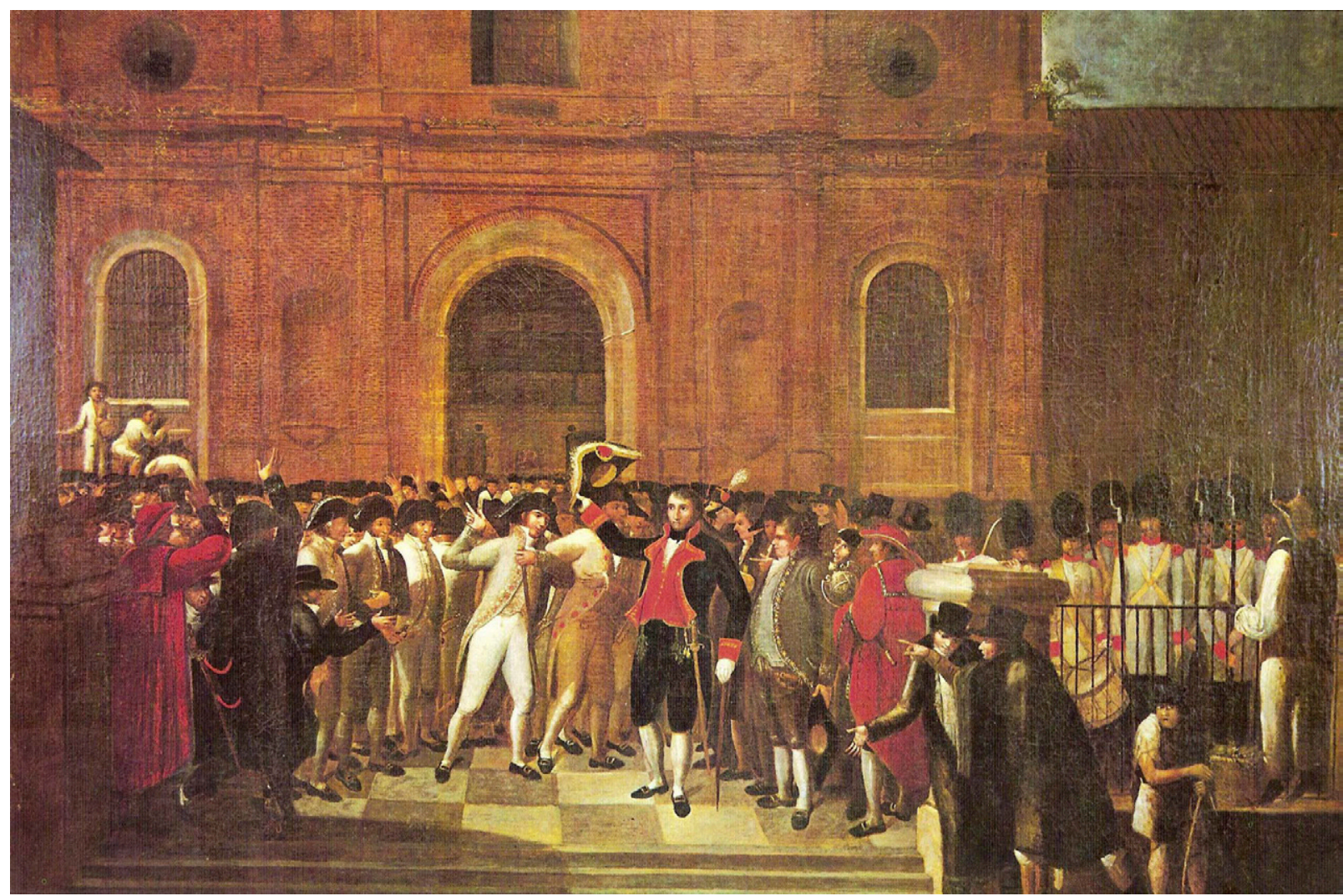

Fig. 6. Juan Lovera, El tumulto del 19 de abril de 1810, 1835. Óleo sobre tela, 139 × $98 \mathrm{~cm}$. Colección Palacio Municipal de Caracas, Caracas, Venezuela.

También podía contemplarse a través de las ventanas de la casa de María Antonia Bolívar, en la esquina de las Gradillas.

Posiblemente muchos retratos del Libertador pintados en estas fechas desaparecieron después de 1830, cuando se produjo la disolución de la llamada Gran Colombia y la reacción antibolivariana que perduraría hasta 1842 , cuando se repatriaron sus restos.

Si bien parte de la forma de vida y el pensamiento típicas del antiguo régimen se mantienen con ligeras variantes, comienza a imponerse otros modelos culturales y una segunda oleada clasicista irrumpe en Caracas, producto de la apertura hacia otros mercados como Inglaterra, Francia, Alemania y los Estados Unidos. Así comienzan a instalarse algunos artistas extranjeros, como el diplomático, pintor y escritor inglés sir Robert Ker Porter (n. 1777-f. 1842) en 1825, del cual solo se conserva un retrato en acuarela que representa al general José Antonio Páez realizado en 1828.

Luego de este apretado panorama que procura a vuelo de pájaro relatar quienes eran los protagonistas y cuáles fueron los acontecimientos que marcaron la práctica pictórica en este período, quisiera detenerme en un pintor que ejemplifica este momento de transición. 


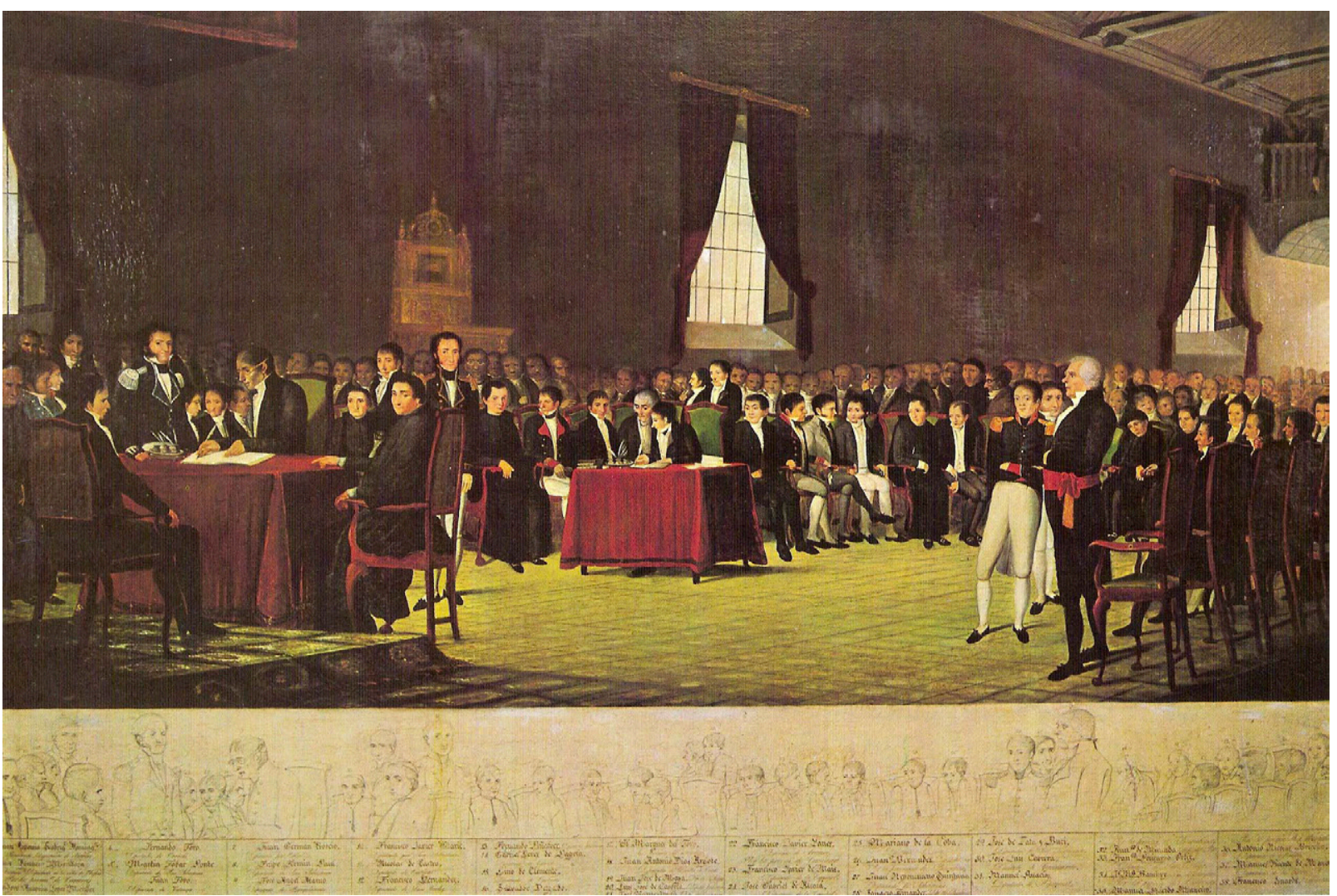

Fig. 7. Juan Lovera, La firma del acta de la independencia, el 5 de julio de 1811, 1838. Óleo sobre tela, $97.5 \times 138 \mathrm{~cm}$. Colección Alcaldía del Municipio Bolivariano Libertador, Caracas, Venezuela.

Juan Lovera: el artista de transición Entre el grupo de jóvenes que intentaron llenar el vacío dejado por Juan Pedro López, hallamos a Juan Lovera (n. el 11 de julio de 1776 y fallecido en 1841), un pintor formado en el taller del convento de San Jacinto, con los frailes dominicos; y en el año 1798, en el taller del maestro Antonio José Landaeta, en el cual habría aprendido el oficio de preparar y mezclar colores, la copia de grabados, la preparación de lienzos y el dorado de hojilla. Al año siguiente muere el maestro Landaeta, y aunque podríamos especular que la formación de Lovera no se había completado, este opta por abrir su propio taller, en el que habría supuestamente retratado a Alexander von Humboldt (1769-1859) durante su visita en 1799. Aunque a despecho de algunos críticos Humboldt no hizo ninguna referencia a este artista y tampoco a la práctica pictórica en Caracas, mientras si destacó el gusto por la música y la literatura que definía a los caraqueños en esas fechas. ${ }^{32}$ Observación que repiten otros viajeros ilustrados que frecuentaron la ciudad desde entonces.

Regresando a Lovera, entre 1800 y 1814 es poco lo que se conoce de su producción, dedicado aparentemente a cumplir con algunos encargos para diversas iglesias caraqueñas. Lovera emigró hacia el oriente cuando el general Boves arremetió contra Caracas en julio de 1814, y de allí pasó una larga temporada en alguna isla del Caribe hasta su regreso en 1820, fecha en la que está datada su Divina Pastora de la Galería de Arte Nacional 
(Caracas). Al año siguiente dictaba clases como maestro de dibujo en una escuela que dirigía Felipe Limardo y ocupaba el cargo de corregidor de la ciudad. En 1824 el cabildo le nombra Maestro Mayor de Pintura, cargo que rechaza por estar ocupado como representante en el congreso. Mientras tanto efectúa numerosos retratos, convirtiéndose en uno de los más importantes retratistas de Caracas, hasta su muerte en 1841.

Lovera ha sido catalogado como el Pintor de los Próceres, gracias a dos obras, que aunque elaboradas fuera del lapso que nos ocupa en esta cátedra son ineludibles. En estas representó dos sucesos que se consideran fundacionales en la historia patria: El tumulto del 19 de abril de 1810 (Fig. 6) y La firma del acta de la independencia, el 5 de julio de 1811 (Fig. 7) pintados en 1835 y 1838 respectivamente; ambos sucesos se habían convertido en fechas patrias por decreto del Congreso en 1834, durante el primer gobierno del general Páez. Si bien estas dos obras han sido consideradas como el producto de un testigo de los hechos que decide donarlas al Cabildo metropolitano, precisamente para dejar un testimonio visual a las generaciones futuras, no se trata de obras que hayan dejado honda huella en el imaginario colectivo del venezolano, ni tampoco contribuyeron en mayor medida a generar una iconografía posterior.

En la primera pieza se muestra el momento cuando el alférez real Feliciano Palacios y Blanco, y el edil Francisco Salias obligaron al capitán general Vicente Emparan (1747-1820), a regresar a la sede del Cabildo, hecho ocurrido frente a la catedral de Caracas y en medio de la multitud que ingresaba al templo para asistir a los oficios litúrgicos de la Semana Santa. Tras este incidente que provocó la renuncia del capitán general, se creó la Junta Conservadora de los Derechos de Fernando VII que desconoció al Consejo de la Regencia. Aún no se conocen las posibles fuentes gráficas que inspiraron esta composición, y cabe acotar que es la única imagen elaborada durante el siglo XIX que plasma este suceso fundacional de la historia venezolana.

Este cuadro de Lovera fue exhibido en la Sala de la Diputación "como un monumento histórico y artístico" 33 según palabras del gobernador de la provincia. En los años siguientes la obra era sacada en procesión por el centro de la ciudad, durante las festividades que se organizaban en cada aniversario del 19 de abril, aunque progresivamente fue perdiendo protagonismo.

El segundo cuadro representa la firma del Acta de Independencia en el Congreso General de Venezuela de 1811, que se realizó al interior de la capilla de la universidad y seminario de Caracas. Para esta obra se cree que Lovera pudo haberse basado en el cuadro Declaración de la Independencia 4 de julio de 1776 del pintor estadounidense John Trumbull (1756-1843), encargada por el Congreso de los Estados Unidos en 1817 y exhibida en el Capitolio de Washington desde 1829. ${ }^{34}$ Aunque no se tiene claro cómo Lovera habría entrado en contacto con esta pieza, se cree que ocurrió a través de su relación con el comerciante inglés John Alderson (1785-1846), ${ }^{35}$ quien le habría servido de enlace con el pintor norteamericano John Neagle (17961865). Este último tenía entre sus posesiones un retrato de Bolívar, pintado por Lovera posiblemente en 1827 y obsequiado a Neagle en $1835^{36}$.

33. Duarte, Diccionario biográfico documental, 180

34. Cordelia Arias Toledo, "El tumulto del 19 de abril de Juan Lovera. Una pintura histórica en el período de transición 1810-1841," Boletín de la Academia Nacional de la Historia 87, no. 347 (2004): 117.

35. John Alderson había nacido en Inglaterra en 1785. Llegó a Caracas en 1811 y simpatizó con la causa independentista. En 1824 traslada a su familia desde la isla de Trinidad a Caracas, en donde establece una casa comercial que importaba harina desde Baltimore. Fue amigo personal del Libertador. Fallece en 1846.

36. Hasta mayo de 2010 se encontraba en la colección Historical Society of Pennsylvania, Philadelphia, fecha en la cual fue subastada en Christie's. Desconocemos su paradero actual. 


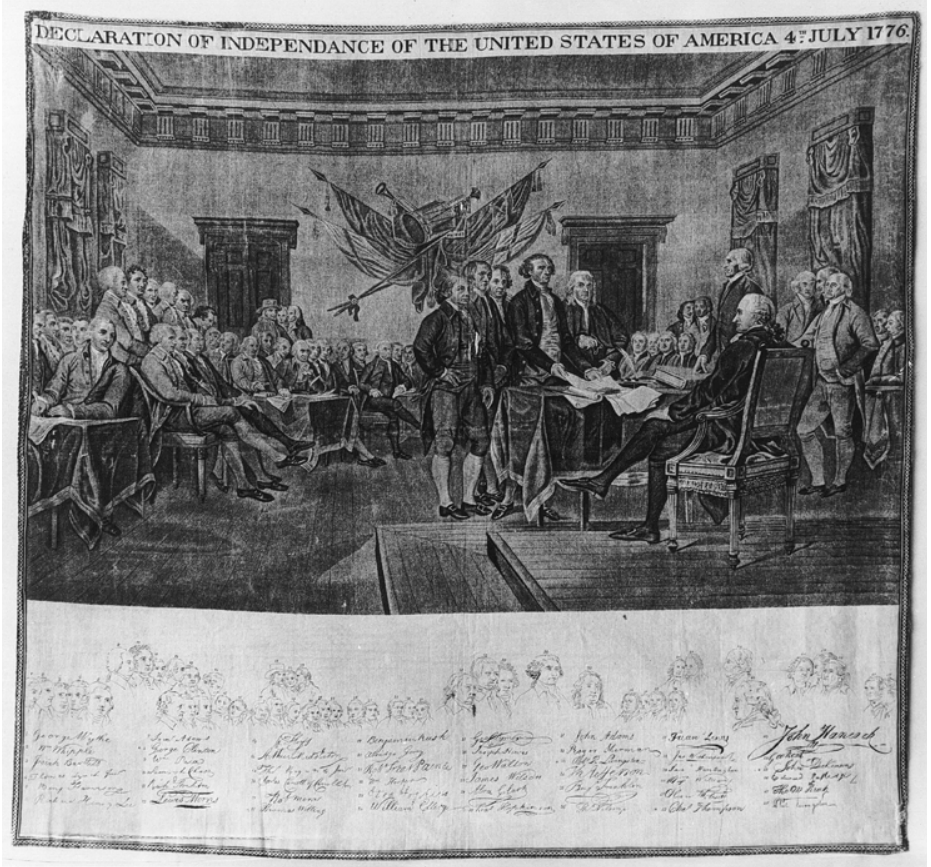

Fig. 8. Anónimo, Pañuelo conmemorativo de la Declaración de la Independencia de los Estados Unidos de América 4 de julio de 1776, inicios del siglo XIX. Textil en algodón impreso, $73 \times 78.4 \mathrm{~cm}$. The Metropolitan Museum of Art, New York, US. Disponible en: https://www.metmuseum.org/art/collection/search/390116
A través de esta relación nos atrevemos a proponer que Lovera pudo conocer un grabado de Asher Brown Durand (1796-1886) que en 1823 reproducía el cuadro norteamericano, y que se acompañaba con otro que mostraba, a modo de clave de lectura, solo las cabezas dibujadas de los signatarios. Cada una marcada con un número, que se correspondía a los nombres y a las firmas. Un detalle que Lovera repitió cuidadosamente en su obra. También en esas primeras décadas del siglo XIX se estampó un pańuelo conmemorativo que reproducía ambos grabados en Norteamérica (Fig. 8).

Nuestro artista obsequió su creación al Cabildo acompañada de una carta en la cual explicaba que:

Un recuerdo de él ha exitado mis cortos conocimientos en la noble profesión que ejerzo. Es acreedor por cierto a los pinceles de los Apeles, de los Rubenes y de los Rafaeles; pero mi amor a mi patria ha superado mi insuficiencia y ha confortado mi justa timidez. En los pensamientos que tienen por sí mismos nobleza y magnitud solo concebirlos trae para sus autores una indulgencia. El tiempo devora a los más notables acontecimientos, así es preciso consignarlos a la posteridad del modo más indeleble posible. A ella toca mejorar y perfeccionar. ${ }^{37}$

Tales palabras evidencian que estaba consciente de sus deficiencias técnicas y habría preferido que artistas más dotados, como los grandes maestros de la pintura occidental, representaran los sucesos de 1811. Pero ante el paso del tiempo se atreve a dejar un testimonio gráfico, con la esperanza de que en el futuro alguien pueda perfeccionar su obra.

Más allá de las nobles intenciones del artista, que actúa por su propia cuenta, sin mediar encargo, hay que leer la elaboración de estos cuadros en relación con un ambiente favorable a la reconstrucción histórica del pasado, y a la configuración de los mitos fundacionales de la historia nacional para la adecuada formación de los ciudadanos. Es precisamente en estas décadas cuando se toma la iniciativa de publicar los primeros libros dedicados a la historia de Venezuela como nación independiente; es el caso de la obra de Feliciano Montenegro y Colón (1781-1853), Geografía general para uso de la juventud en Venezuela publicada en 1833. El objetivo de los primeros historiadores fue armar las bases de una memoria colectiva que permitiera justificar el movimiento emancipador caraqueño y construir un pasado nacional venezolano, independiente de Colombia. A los libros se sumaron otros medios indirectos de instrucción pública como los espectáculos,

37. Juan Lovera, "1838, Cuadro de la Declaratoria de Independencia," en Esteva-Grillet, Fuentes documentales y críticas, 1:107. 
las fiestas nacionales, los desfiles y por supuesto las imágenes, que ayudarían a divulgar los valores patrios y consagrar en la memoria a los personajes que se destacaron en su lucha por la libertad. Por todo ello observamos que la obra de Lovera hace mucho énfasis en retratar a cada uno de los diputados firmantes del Acta de la Independencia, por lo que su obra más que una interpretación artística de un hecho, es un testimonio gráfico de un suceso histórico que se deseaba preservar de la manera más digna posible. Aunque como bien acota el historiador Elías Pino Iturrieta, la sesión del acto de proclamación de la independencia difícilmente se produjo en la aparente calma de los "hombres austeros que vemos en la pintura de Juan Lovera (...) severos en el traje y moderados en el gesto, impasibles en la ceremonia que consagra sus desvelos, representación de un señorial sosiego susceptible de conducirnos a refrendar la firmeza de sus decisiones." ${ }^{38} \mathrm{Al}$ contrario, se trató de un momento de intensas vacilaciones, incertidumbre y severas discusiones.

Podríamos añadir que la selección de las escenas nos indica una toma de posición política por parte del artista, el cual escoge representar dos sucesos de carácter eminentemente civil, y no alguna escena bélica, en medio de unos tiempos políticos turbulentos. No podemos olvidar que recién en 1830 Venezuela se separa de Colombia. Por lo que Lovera brinda la iconografía que permite a la naciente república diferenciarse, contar con un pasado propio y autónomo, y estimular la identidad y el nacionalismo desde una narrativa visual del pasado.

Pese a estos innegables aportes la obra de Lovera ha contado con una fortuna crítica muy variable. Lovera fue el primer artista venezolano merecedor de una crítica periodística, suceso ocurrido en enero de 1811, cuando Francisco Isnardi publicó un breve artículo en el Mercurio Venezolano dedicado a su producción. En este comentó lo siguiente:

La pintura se ha resentido hasta ahora, como todas las demás artes de gusto de América, de la falta de maestros y modelos, que hubieran dado al genio americano todo el impulso que prometen las bellas disposiciones que los inteligentes descubren en los cuadros de algunos de nuestros artistas indígenas. Caracas no desmerece figurar entre las ciudades que han producido pintores de genio, y capaces de honrar las escuelas; si la opresión les hubiera permitido tenerlas, o les hubiera dado fomento y libertad, para llegar a ellas.

El S. Lovera merece por todos los títulos, la protección benéfica de nuestra actual transformación, y sus obras, conocidas de pocos, son una prueba de esta verdad honrosa para Caracas. Es tiempo de que se haga ver al mundo el genio Americano, y las esperanzas que deben hacer concebir sus felices ensayos en la pintura. El S. Lovera ha copiado últimamente los quatro elementos de Lebrun, que posee D. Juan José Rivas y Pacheco, como uno de los mejores adornos de la habitación de un Ciudadano Americano. Esta producción, que es la que podemos citar, como más a mano entre las demás del S. Lovera, no será comparable a las de Murillo, Velázquez, y Mengs; pero anunciará disposiciones capaces de recibir y hacer honor a las lecciones de estos insignes maestros. ${ }^{39}$

Lo primero que llama la atención es el trasfondo político en las palabras de Isnardi, ya que la obra de Lovera no es realmente el tema central del texto, sino una excusa para demostrar las ventajas de la vida republicana, al tiempo que se denigra del antiguo régimen. Otro aspecto que descuella es la variedad de re-

38. Elías Pino Iturrieta, La independencia a palos, y otros ensayos (Caracas: Editorial Alfa, 2011), 80.

39. Francisco Isnardi, "1811, Pintura [El pintor Juan Lovera]," en Esteva-Grillet, Fuentes documentales y críticas, 1:63. 
ferentes artísticos con los cuales se compara la producción de Lovera, desde los maestros del barroco español hasta lo más insignes representantes del neoclasicismo. Lamentablemente aún no se ha podido identificar la obra de Le Brun que estaba copiando Lovera.

Posteriormente hacia 1883 el general Ramón de la Plaza (ca. 1831-1886), autor de Ensayos sobre el arte en Venezuela, primer libro dedicado a la actividad artística en el país, confundió la obra de Juan Lovera con la de Pedro Lovera, de quien se desconoce si fue hijo o sobrino del pintor. En este fin de siglo la obra de Juan Lovera pasó prácticamente desapercibida para los artistas académicos que se dedicaron a plasmar la historia patria, lo mismo que para el público. De hecho sus obras no se mencionan en las grandes exposiciones organizadas en torno al centenario del natalicio del Libertador en 1883. Mientras en 1911 cuando se cumplió el primer centenario de la firma del Acta de la Independencia, solo se exhibió su cuadro el 5 de julio de 1811 en la exposición de la Academia de Bellas Artes. ${ }^{40}$ A los ojos del espectador de fin de siglo la obra de Lovera no resistía la comparación con la producción académica, por lo que era poco menos que un artesano atado a un legado cultural que no se identificaba con los nuevos proyectos de civilización y progreso auspiciados desde el poder político.

A inicios del siglo XX, Manuel Landaeta Rosales (1847-1920) le consagra un estudio titulado "Los antiguos pintores venezolanos Juan y Pedro Lovera" publicado en El Constitucional, en el cual abundó en datos biográficos y mencionó varias obras que había podido apreciar en colecciones privadas. Aquí por primera vez se reconoció su producción como un relato visual de los sucesos históricos, al tiempo que se destacó su interés por la enseñanza del dibujo, aunque en palabras de Landaeta Rosales: "no para transmitir a sus alumnos conocimientos que ignoraba, sino el ardor de su entusiasmo y el ejemplo del culto que guardaba por el arte.”41

Los siguientes autores que se dedicaron a escribir sobre la pintura venezolana escasamente se ocuparon de Lovera. Si bien reconocieron el valor histórico de sus obras, al mismo tiempo acusaban la falta de técnica, al punto de calificarlo como un pintor aficionado. ${ }^{42}$

En 1960 Alfredo Boulton (1908-1995) organizó en el Museo de Bellas Artes la primera exposición dedicada a la obra de Lovera, reuniendo veintiún cuadros que le atribuyó por comparación de estilo con las pocas piezas firmadas. Para Boulton la obra de Lovera sería la de un precursor de vastos conocimientos, con absoluto dominio de su profesión, sin el cual "los próceres que nos dieron la independencia habrían muerto con los rostros ocultos (...) Pero se da el caso de que este caraqueño no es solamente el cronista gráfico de tan solemnes días, sino también un excelente pintor de alta calidad plástica.” ${ }^{3}$

Tras esta revalorización de la obra de Lovera, serán varios los estudios que la mencionen. Sin embargo, podríamos agrupar la crítica en dos grandes vertientes: los que procuran ampliar los datos biográficos, como es el caso de Carlos Duarte ${ }^{44}$ que logra aumentar hasta una treintena el catálogo de piezas atribuidas; y quienes intentan explicar su estilo, como Francisco Da Antonio, quien lo propone como representante de un nuevo estilo que bautiza como Arclásico, ${ }^{45}$ propuesta que afortunadamente tuvo poca trascendencia.

40. Roldán Esteva-Grillet, Las artes plásticas venezolanas en el centenario de la independencia 1910-1911 (Caracas: Academia Nacional de la Historia, 2010$), 71$.

41. Manuel Landaeta Rosales, "1906, Los antiguos pintores venezolanos Juan y Pedro Lovera," en Esteva-Grillet, Fuentes documentales y críticas, 1:603.

42. Un ejemplo de ello es el texto de Enrique Planchart, "El pintor Juan Lovera," en La pintura en Venezuela (Caracas: Equinoccio, 1979), 91-105.

43. Alfredo Boulton, "1960, Juan Lovera," en Esteva-Grillet, Fuentes documentales y críticas, 2:446.

44. Carlos Duarte, Juan Lovera. El pintor de los próceres (Caracas: Editorial Arte, 1985).

45. Francisco Da Antonio, El arte ingenuo en Venezuela (Caracas: Compañía Shell, 1974), 16. 
Así la crítica ha sido displicente con Lovera, se le recuerda como el primer pintor histórico del país, pero se le reprocha su incompetencia formal y técnica, su apego a las formulas barrocas, la ausencia de perspectiva, la frontalidad hierática y severa, etc. Lo que en síntesis no sería más que una interpretación ingenua y candorosa de las complejidades del arte neoclásico europeo. Pero como otros artistas de la misma época adolecen de similares defectos, se consideró entonces a Lovera como un representante de un "arte marginal", "menor y primitivo", que se prolonga hasta la segunda mitad del siglo XIX; para vergüenza de algunos que habrían preferido que la ruptura con el antiguo régimen se hubiese reflejado también en un salto rotundo hacia un academicismo neoclásico, y no en la prolongación de formas aún apegadas a una tradición que convenía olvidar, junto al país indígena y mestizo. Incluso se ha intentado crear una cronología pictórica en la cual la obra de Lovera representaría la "edad temprana de la pintura" en Venezuela, borrando de un solo plumazo toda la producción artística anterior. ${ }^{46}$

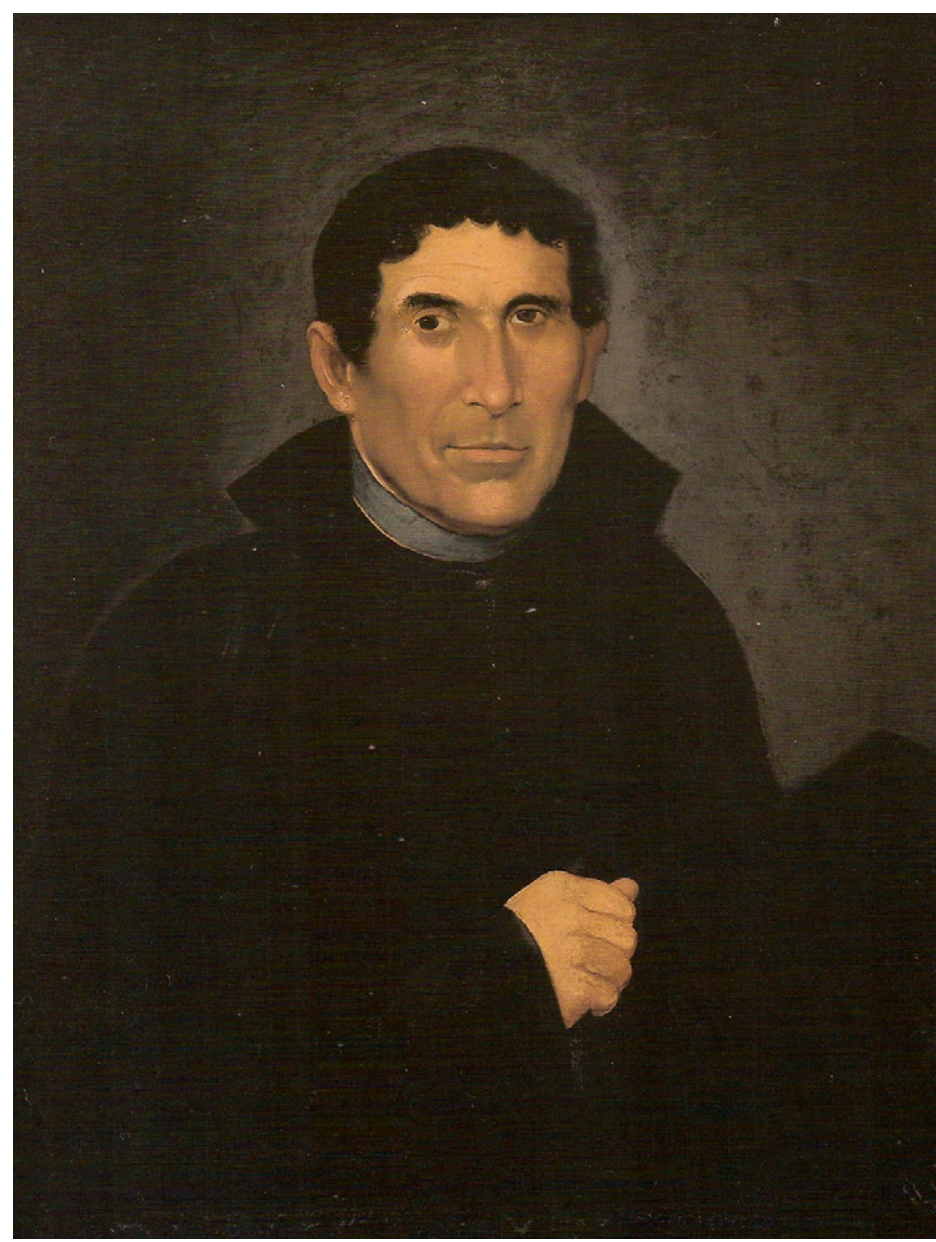

Fig. 9. Juan Lovera, Presbítero Sixto Domingo Freites, 1831. Óleo sobre tela, $71 \times 57.5 \mathrm{~cm}$. Galería de Arte Nacional, Caracas, Venezuela.

Pocos críticos han apreciado la obra de Lovera como representación de los grupos de poder emergentes, constituidos por militares y burgueses, que tienen un gusto por la pintura, la música y la literatura. Estos nuevos protagonistas requieren del uso de dispositivos como el retrato, que les permitan crear unas genealogías y un pasado de distinción social. En este punto conviene además recordar que el interés de la sociedad caraqueña contemporánea a Lovera no se hallaba en la creatividad del artista o en su conocimiento de las últimas tendencias del arte europeo, sino en su habilidad para captar la semejanza con el modelo. Así el parecido contribuía a mantener el recuerdo de los seres queridos, mientras en otras ocasiones convertía al retrato en una imagen gratificante del yo, un soporte de la vanidad y el prestigio.

Por todo ello la retratística de Lovera no puede desprenderse completamente de la tradición barroca, conservando en muchos casos los convencionalismos del aparato simbólico, que se empleaba para identificar

46. Un amplio estudio sobre la historiografía referente a Juan Lovera se encuentra en el trabajo inédito de Vanessa Romero, "Juan Lovera más allá del arclásico. Una revisión del término arclásico en los retratos de ostentación" (tesis de licenciatura, Universidad Central de Venezuela, 2009). 
visualmente la posición social y económica del retratado. Pese a que ya se conocían en Caracas los retratos sobre fondos neutros, más acordes a la sensibilidad austera republicana que procuraba eludir la referencia corporativa y centrar la atención en la figura. Un ejemplo de ello son los retratos anónimos conservados en la Galería de Arte Nacional en Caracas: El Hombre del chaleco (ca. 1812) y el Caballero de la familia Guadalajara (ca. 1815).

Es evidente que buena parte de la clientela de Lovera parece preferir el lenguaje más convencional. No debemos olvidar que quien encargaba la obra tenía un importante peso en la configuración final de la misma, por lo que no resultaría extraño que una parte de la clientela prefiriera modelos más tradicionales, obligando al artista a permanecer fiel a sus raíces plásticas. También cuando le toca hacer retratos dobles como Nicanor Borges recibiendo las proposiciones académicas de su hijo Nicolás, datado alrededor de 1838 (Galería de Arte Nacional), opta por composiciones con figuras en diagonal y agrega ambientes con muebles, manteles y objetos diversos que recuerdan la práctica pictórica colonial. Mientras en otros pocos casos como el retrato del Presbitero Sixto Domingo Freites fechado en 1831 (Galería de Arte Nacional), percibimos soluciones más modernas como el uso de los fondos neutros y la ausencia de escenografías (Fig. 9), lo que nos demuestra que Lovera perfectamente podía alternar ambos lenguajes. Hay que aceptar entonces que estamos ante una interpretación legítima de la realidad, en la cual se reconocían sus contemporáneos, que se mantenían fieles a unos hábitos visuales que irán cambiando lentamente en medio de las dificultades económicas y sociales.

Las soluciones plásticas empleadas por Lovera se sustentaron en su formación, creando un discurso propio alejado de los rigurosos y áridos cánones académicos, con alternativas de expresión más sencillas, adaptadas al gusto local. Esa combinación entre la práctica artística barroca y la sensibilidad republicana que se encuentra en la obra de Lovera, no pudo ser perdonada por una historiografía que pretendía hacer tabula rasa con la cultura del antiguo régimen. De allí que, junto a Lovera, muchos artistas de este período hayan sido olvidados, y no exista en estos momentos de hipertrofia de la épica militar interés alguno en su estudio, salvo muy contadas excepciones. ${ }^{47}$

\section{Referencias}

Altez, Rogelio. El desastre de 1812 en Venezuela: sismos, vulnerabilidades y una patria no tan boba. Caracas: Universidad Católica Andrés Bello, Fundación Empresas Polar, 2006.

Arias Toledo, Cordelia. "El tumulto del 19 de abril de Juan Lovera. Una pintura histórica en el período de transición 1810-1841." Boletín de la Academia Nacional de la Historia 87, no. 347, (2004): 113-27.

Boulton, Alfredo. "1960, Juan Lovera." En Fuentes documentales y críticas de las artes plásticas venezolanas: siglos XIX y XX, compilado por Roldán Esteva-Grillet, 431-48. Vol. 2. Caracas: Universidad Central de Venezuela, Consejo de Desarrollo Científico y Humanístico, 2001.

Da Antonio, Francisco. El arte ingenuo en Venezuela. Caracas: Companía Shell, 1974.

Duarte, Carlos. Juan Lovera. El pintor de los próceres. Caracas: Editorial Arte, 1985.

---. Diccionario biográfico documental. Pintores, escultores y doradores en Venezuela. Periodo hispánico y comienzos del periodo republicano. Caracas: Fundación Galería de Arte Nacional, Fundación Polar, 2000.

Esteva-Grillet, Roldán. Vida y obra de Pedro Castillo (1790-1858). Caracas: Biblioteca de la Academia Nacional de la Historia, 2004.

47. Tal es el caso del pintor Pedro Castillo estudiado por Esteva-Grillet, Vida y obra de Pedro Castillo. 
---. "Iconografía europeo-americana de Bolívar." En Studi Latinoamericanil Estudios Latinoamericanos, No. 2: Nazioni e Identitá Plurime, coordinado por Mario Sartor, 161-88. Udine: Universitá degli Studi di Udine, 2006.

---. Las artes plásticas venezolanas en el centenario de la independencia 1910-1911. Caracas: Academia Nacional de la Historia, 2010.

Franco, José Juan. "1809, Solicitud de permiso para abrir una escuela de dibujo." En Fuentes documentales $y$ críticas de las artes plásticas venezolanas: siglos XIX y XX, compilado por Roldán Esteva-Grillet, 6. Vol. 1. Caracas: Universidad Central de Venezuela, Consejo de Desarrollo Científico y Humanístico, 2001.

Gazeta de Caracas. "1812, M.H. Garnezey, dibujante y pintor francés, se ofrece para hacer retratos en miniatura y dar clases de pintura." En Fuentes documentales y críticas de las artes plásticas venezolanas: siglos XIX y XX, compilado por Roldán Esteva-Grillet, 73. Vol. 1. Caracas: Universidad Central de Venezuela, Consejo de Desarrollo Científico y Humanístico, 2001.

Isnardi, Francisco. "1811, Pintura [El pintor Juan Lovera].” En Fuentes documentales y críticas de las artes plásticas venezolanas: siglos XIX y XX, compilado por Roldán Esteva-Grillet, 63. Vol. 1. Caracas: Universidad Central de Venezuela, Consejo de Desarrollo Científico y Humanístico, 2001.

---. “1811, José Juan Franco y el grabado.” En Fuentes documentales y críticas de las artes plásticas venezolanas: siglos XIX y XX, compilado por Roldán Esteva-Grillet, 64. Vol. 1. Caracas: Universidad Central de Venezuela, Consejo de Desarrollo Científico y Humanístico, 2001.

Landaeta Rosales, Manuel. "1906, Los antiguos pintores venezolanos Juan y Pedro Lovera.” En Fuentes documentales y críticas de las artes plásticas venezolanas: siglos XIX y XX, compilado por Roldán EstevaGrillet, 603-9. Vol. 1. Caracas: Universidad Central de Venezuela, Consejo de Desarrollo Científico y Humanístico, 2001.

Limardo, José de la Cruz. "1841, Memorias.” En Fuentes documentales y críticas de las artes plásticas venezolanas: siglos XIX y XX, compilado por Roldán Esteva-Grillet, 138-39. Vol. 1. Caracas: Universidad Central de Venezuela, Consejo de Desarrollo Científico y Humanístico, 2001.

Lovera, Juan. "1838, Cuadro de la Declaratoria de Independencia." En Fuentes documentales y críticas de las artes plásticas venezolanas: siglos XIX y XX, compilado por Roldán Esteva-Grillet, 107-8. Vol. 1. Caracas: Universidad Central de Venezuela, Consejo de Desarrollo Científico y Humanístico, 2001.

Mckinley, Peter Michael. Caracas antes de la independencia. Caracas: Monte Ávila Editores Latinoamericana, 1993.

Michelena, Juan Antonio. “1859, Apuntes biográficos de Pedro Castillo, pintor y escultor en Valencia.” En Fuentes documentales y criticas de las artes plásticas venezolanas: siglos XIX y XX, compilado por Roldán Esteva-Grillet, 220-23. Vol. 1. Caracas: Universidad Central de Venezuela, Consejo de Desarrollo Científico y Humanístico, 2001.

Noriega, Simón. Ideas sobre el arte en Venezuela en el siglo XIX. Mérida: Universidad de los Andes, Ediciones del Rectorado, 1993.

Palacios y Blanco, Esteban. "1828 Carta a Simón Bolívar.” En Fuentes documentales y críticas de las artes plásticas venezolanas: siglos XIX y XX, compilado por Roldán Esteva-Grillet, 95. Vol. 1. Caracas: Universidad Central de Venezuela, Consejo de Desarrollo Científico y Humanístico, 2001.

Planchart, Enrique. La pintura en Venezuela. Caracas: Equinoccio, 1979.

Pino Iturrieta, Elías. La mentalidad venezolana de la emancipación (1810-1812). Caracas: Eldorado ediciones, 1991. 
---. La independencia a palos, y otros ensayos. Caracas: Editorial Alfa, 2011.

Quintero, Inés, coord. Más allá de la guerra. Venezuela en tiempos de la independencia. Caracas: Fundación Bigott, 2008.

Rodríguez Nóbrega, Janeth. "El rey en la hoguera: la destrucción de los retratos de la monarquía en Venezuela." En VI Encuentro Internacional sobre Barroco. Imagen del poder, coordinado por Norma Campos, 89-95. La Paz: Editorial Visión Cultural, 2012.

Romero, Vanessa. "Juan Lovera más allá del arclásico. Una revisión del término arclásico en los retratos de ostentación.” Tesis de licenciatura, Universidad Central de Venezuela, 2009.

Salvador González, José María. "La enseñanza del arte en Venezuela durante la primera mitad del siglo XIX." Escritos en arte, estética y cultura, no. 17-18 (2003): 175-96.

Sociedad Económica Amigos del País. "1833, Cuadro general de artesanos según sus clases en la provincia de Caracas." En Fuentes documentales y críticas de las artes plásticas venezolanas: siglos XIX y XX, compilado por Roldán Esteva-Grillet, 100. Vol. 1. Caracas: Universidad Central de Venezuela, Consejo de Desarrollo Científico y Humanístico, 2001. 